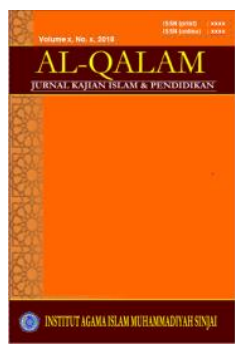

AL-QALAM

Jurnal Kajian Islam \& Pendidikan

Volume 06 No 022014

ISSN (print) : 1858-4152

ISSN (online) : -

Homepage : http://journal.iaimsiniai.ac.id/index.php/al-qalam

\title{
KINERJA GURU DALAM MENINGKATKAN KECERDASAN (IQ) PESERTA DIDIK
}

\author{
Oleh : Jamaluddin ${ }^{1}$
}

\begin{abstract}
$* * *$
Abstrak

Guru adalah merupakan suatu profesi yang dituntut mengembangkan Kompetensinya kemampuan profesi yang dimiliki oleh seorang guru mencakup, penguasaan kurikulum, materi pelajaran yang diajarkan, keterampilan menggunakan metode yang bervariasi, penggunaan media, keterampilan melaksanakan evaluasi pengajaran, mempunyai tanggung jawab yang tinggi serta memiliki kedisiplinan terhadap tugasnya. Tugas guru diantaranya adalah ; 1) Profesi Guru sebagai Pendidik, 2) Profesi Guru sebagai Pengajar, 3) Profesi Guru sebagai Pelatih dan Pembimbing. Dengan demikian seorang guru diharapkan mampu mengarahkan peserta didik dalam mengembangkan kecerdesan intelegensi IQ (Intelligence Quotient) sehingga peserta didik mampu keluar dalam berbagai macam permasalahan yang dihadapinya.
\end{abstract}

Kata Kunci : Kinerja Guru, Kecerdasan IQ.

\section{PENDAHULUAN}

elama ini, wacana merosotnya kualitas proses pendidikan selalu dikaitkan - dengan rendahnya kualitas guru sebagai penyelenggara proses pendidikan. Idealnya, untuk dapat mencapai hasil maksimal, guru harus berkualitas dan teruji kualifikasinya. Oleh karena itulah, program sertifikasi yang diselenggarakan pemerintah benar-benar merupakan program yang signifikan dengan upaya peningkatan kualitas dan kompetensi guru pada bidang keahliannya. Program sertifikasi memang diarahkan untuk melakukan klarifikasi dan evaluasi atas kelayakan guru dalam melaksanakan program pendidikan dan pembelajaran.

Kualitas guru sebagai penyelenggara proses pendidikan memang akhirakhir ini dipertanyakan, bahkan diragukan oleh banyak pihak. Sebenarnya mereka tidak meragukan kualitas dirinya, tetapi lebih pada kelayakan mereka melakukan proses pendidikan dan pembelajaran. Masyarakat sudah mengetahui bahwa cukup

\footnotetext{
${ }^{1}$ Dosen tetap STAI Muhammadiyah Sinjai
} 


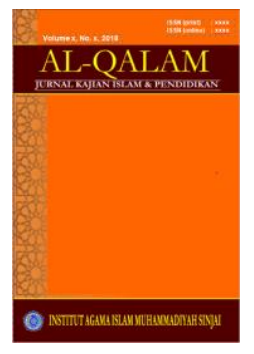

AL-QALAM

Jurnal Kajian Islam \& Pendidikan

Volume 06 No 022014

ISSN (print) : 1858-4152

ISSN (online) : -

Homepage : http://journal.iaimsiniai.ac.id/index.php/al-galam

banyak guru yang tidak berdasar pada disiplin ilmu pendidikan pada bidang pelajaran yang diajarkan di kelas pembelajaran. Secara teoritis, mereka memang menguasai materi pelajaran sebab mereka berasal dari ilmu murni untuk disiplin ilmu yang dipelajari, tetapi mereka sama sekali tidak pernah mendapatkan pembelajaran pendidikan. Mereka hanya mendapatkan materi pelajaran secara murni dan tidak mendapatkan materi bagaimana cara mengajarkan materi tersebut dan bagaimana cara menyelenggarakan proses pendidikan yang efektif. ${ }^{2}$

Kelayakan seseorang menyandang status atau profesi sebagai seorang guru tergantung pada kualitas dirinya. Dengan demikian, agar kita dapat meningkatkan hasil proses pendidikan, kualitas gurunya haruslah tinggi. Artinya, para guru yang menyeleggarakan proses pendidikan dan pembelajaran haruslah benar-benar mempunyai kualifikasi yang memadai untuk itu. Sebagaimana yang telah dicanangkan dalam Undang-Undang Guru dan Dosen (UUGD), ada syarat seseorang agar dapat menjadi guru yang layak, misalnya minimal latar belakang pendidikannya adalah Strata Satu (S1) yang dilengkapi dengan Akta IV. ${ }^{3}$

Dengan demikian, guru ideal semestinya mempunyai pengetahuan tingkat kecerdasan peserta didik yang dihadapi di kelas. Dalam mengorganisir pembelajaran, guru harus memperhatikan taraf kesanggupan mereka, dan merangsang untuk menentukan apa yang terbaik dilakukan untuk dirinya. Belajar dengan penuh makna harus dilaksanakan sesuai kesanggupan dan tujuan peserta didik sendiri dengan prosedur experimental yang berlaku. Berdasar pada itu, guru harus memperhatikan faktor-faktor yang mempengaruhi perbedaan kecerdasan peserta didik, antara lain pembawaan, kematangan, pembentukan, minat dan pembawaan khas dan kebebasan. ${ }^{4}$

Kualitas diri merupakan cermin keberhasilan proses pembelajaran yang diselenggarakan oleh guru. Semakin berkualitas guru, semakin berkualitas proses yang diselenggarakan. Hal tersebut secara implisit sudah menggambarkan tingkat keberhasilan peserta didik dalam pencapaian materi dan penguasaan kompetensi yang dipelajari. Selanjutnya, hal tersebut sudah jelas mengindikasi keterampilan anak didik dalam pola kehidupan masyarakat.

\section{PEMBAHASAN}

\section{A. Tinjauan Tentang Kinerja Guru}

2 Mohammad Saroni, Personal Branding Guru, (Cet, I; Jogjakarta: Ar-Ruzz Media, 2010), h. 101 .

3 Ibid., h. 105.

4 Slameto, Belajar dan Faktor-faktor yang Mempengaruhinya, (Jakarta: Rineka Cipta, 2003), h. 90. 


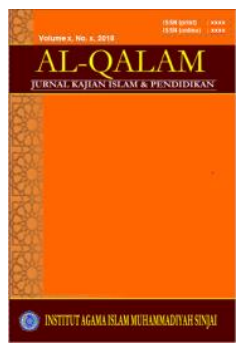

\section{AL-QALAM}

Jurnal Kajian Islam \& Pendidikan

Volume 06 No 022014

ISSN (print) : 1858-4152

ISSN (online) : -

Homepage : http://journal.iaimsiniai.ac.id/index.php/al-qalam

\section{Pengertian Kinerja Guru}

Pengertian kinerja menurut kamus besar bahasa indonesia adalah sesuatu yang dicapai, prestasi yang diperlihatkan, dan kemampuan kerja ${ }^{5}$ Kata kinerja (performance) dalam konteks tugas, sama dengan prestasi kerja. Para pakar banyak memberikan definisi tentang kinerja secara umum, Kinerja adalah pekerjaan yang merupakan gabungan dari karakteristik pribadi dan pengorganisasian seseorang Sementara Muhammad As'ad, mendefinisikan kinerja sebagai keberhasilan seseorang dalam melaksanakan suatu pekerjaan ${ }^{6}$.

Sedangkan yang dimaksud dengan kinerja adalah penampilan hasil kerja pegawai baik secara kuantitas maupun kualitas. Kinerja dapat berupa penampilan kerja perorangan maupun kelompok. Kinerja organisasi merupakan hasil interaksi yang kompleks dan agregasi kinerja sejumlah individu dalam organisasi. Kinerja mengandung dua komponen penting yaitu : 1). Kompetensi berarti individu atau organisasi memiliki kemampuan untuk mengidentifikasikan tingkat kinerjanya; 2). Produktifitas adalah kompetensi tersebut diatas dapat diterjemahkan kedalam tindakan atau kegiatan-kegiatan yang tepat untuk mencapai hasil kinerja (outcome) $)^{7}$.

Dari berbagai pengertian tersebut diatas, pada dasarnya kinerja menekankan apa yang dihasilkan dari fungsi-fungsi suatu pekerjaan atau apa yang keluar (outcome). Bila di simak lebih lanjut apa yang terjadi dalam sebuah pekerjaan atan jabatan adalah suatu proses yang mengolah input menjadi output (hasil kerja). Penggunaan indikator kunci untuk mengukur hasil kinerja individu, bersumber dari fungsi-fungsi yang diterjemahkan dalam kegiatan/tindakan dengan landasan standar yang jelas dan tertulis. Mengingat kinerja mengandung komponen kompetensi dan produktifitas hasil, maka hasil kinerja sangat tergantung pada tingkat kemampuan individu dalam pencapaiannya.

\section{Kriteria Kinerja Guru}

Di dalam Undang-Undang No. 14 Tahun 2005 tentang Guru dan Dosen Bab VI tentang Standar Pendidik dan Tenaga Kependidikan, pasal 28 dijelaskan bahwa

${ }^{5}$ Departemen Pendidikan dan Kebudayaan, Kamus Besar Bahasa Indonesia, (Edisi Kedua Balai Pustaka. 1991).

${ }^{6}$ Muhammad As'ad.. Psikologi Industri: Seri Sumber Daya Manusia. (Yogjakarta : Liberty. 2003) h. 49

${ }^{7}$ Ilyas Yaslis, Kinerja, Teori, Penilaian dan Penelitian. (Jakarta: Pusat Kajian Ekonomi Kesehatan FKM Universitas Indonesia. 2002), h.65. 


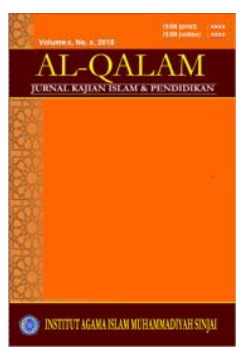

\section{AL-QALAM}

Jurnal Kajian Islam \& Pendidikan

Volume 06 No 022014

ISSN (print) : 1858-4152

ISSN (online) : -

Homepage : http://journal.iaimsiniai.ac.id/index.php/al-qalam

seorang guru harus memiliki sedikitnya empat kompetensi dasar yaitu kompetensi pedagogik, kompetensi kepribadian, kompetensi profesional dan kompetensi sosial yang diperoleh melalui pendidikan profesi ${ }^{8}$.

Wina Sanjaya (2008) dalam Abd. Rahman Getteng mengemukakan bahwa guru sebagai jabatan profesional diharapkan bekerja melaksanakan fungsi dan tujuan sekolah harus memiliki kompetensi-kompetensi yang ditetapkan dalam undang-undang.

Kompetensi-kompetensi tersebut meliputi:

a. Kompetensi pedagogik adalah merupakan kemampuan guru dalam pengelolaan pembelajaran peserta didik yang sekurang-kurangnya meliputi:

(1). Pemahaman wawasan atau landasan kependidikan;

(2). Pemahaman terhadap Peserta didik;

(3). Pengembangan Kurikulum/Silabus;

(4). Perancangan pembelajaran;

(5). Pelaksanaan pembelajaran yang mendidik dan dialogis;

(6). Evaluasi hasil belajar; dan

(7). Pengembangan peserta didik untuk mengaktualisasikan berbagai potensi yang dimilikinya.

b. Kompetensi kepribadian sekurang-kurangnya mencakup kepribadian yang :

(1). Mantap;

(2). Stabil;

(3). Dewasa;

(4). Arif dan bijaksana;

(5). Berwibawa;

(6). Berakhlak mulia ;

(7). Menjadi teladan bagi pesesrta didik;

(8). Secara obyektif mengevaluasi diri sendiri, dan

(9). Mengembangkan diri secara mandiri dan berkelanjutan.

c. Kompetensi sosial, merupakan kemampuan guru sebagai bagian dari masyarakat yang sekurang-kurangnya meliputi kompetensi untuk:

(1). Berkomunikasi lisan, tulisan, dan atau isyarat

(2). Mengusahakan teknologi komunikasi dan informasi secara fungsionla;

(3.) Bergaul secara efektif dengan peserta didik, sesama pendidik, tenaga kependidikan, orang tua/wali peserta didik, dan

${ }^{8}$ Undang-Undang Nomor 14 Tahun 2005. tentang Guru dan Dosen, (Jakarta : CV. Tamita Utama), h. 153 


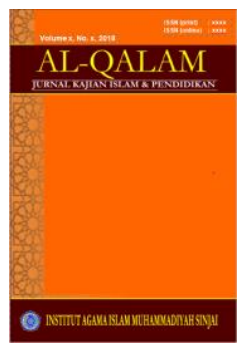

AL-QALAM

Jurnal Kajian Islam \& Pendidikan

Volume 06 No 022014

ISSN (print) : 1858-4152

ISSN (online) : -

Homepage : http://journal.iaimsiniai.ac.id/index.php/al-qalam

(4). Bergaul secara santun dengan masyarakat sekitar.

d. Kompetensi profesional adalah kemampuan penguasaan materi pembelajaran secara luas dan mendalam ${ }^{9}$.

Dengan demikian seorang guru pada dasarnya memiliki tugas yang sangat banyak, baik tugas yang berkaitan dengan dinas maupun tugas di luar dinas, yaitu dalam bentuk pengabdian, yang mana tugas tersebut dapat di kelompokkan menjadi tiga jenis yakni tugas dalam bidang profesi, tugas kemanusiaan dan tugas dalam bidang kemasyarakatan.

Dalam bidang kemanusiaan, seorang guru harus menjadi orang tua ke-dua, guru harus mampu menarik simpati sehingga menjadi idola para peserta didiknya. Pelajaran apa pun yang diberikan hendaknya dapat menjadi motivasi bagi peserta didiknya dalam belajar. Apabila seorang guru dalam berpenampilan saja sudah tidak menarik maka kegagalan pertama adalah ia tidak akan dapat menanamkan benih pengajarannya itu kepada para peserta didiknya. Para peserta didik yang menghadapi guru yang tidak menarik, maka mereka tidak dapat menerima pelajaran dengan maksimal ${ }^{10}$.

Tugas guru sebagai profesi, meliputi mendidik, mengajar dan melatih. Mendidik berarti meneruskan dan mengembangkan nilai-nilai hidup. Mengajar berarti meneruskan dan mengembangkan ilmu pengetahuan dan teknologi. Sedangkan melatih berarti mengembangkan keterampilan-keterampilan para peserta didik. Tugas guru dalam kemasyarakatan yaitu untuk mencerdaskan dan mengajar masyarakat untuk menjadi warga negara yang bermoral pancasila serta mencerdaskan bangsa Indonesia. Firman Allah Swt Q.S. Al-Isra ayat 17:36 :

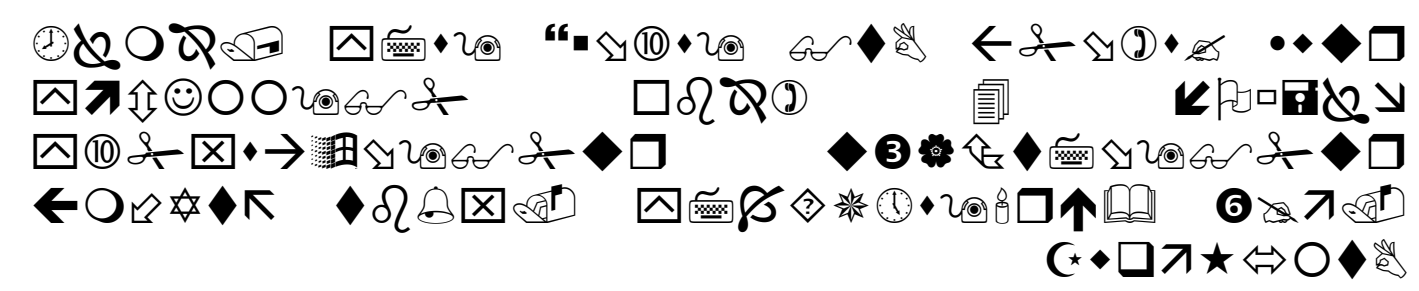

Terjemahan : Dan janganlah kamu mengikuti apa yang kamu tidak mempunyai pengetahuan tentangnya. Sesungguhnya

\footnotetext{
${ }^{9}$ Abd. Rahman Getteng, Menuju Guru Profesional dan Ber-Etika, (Cet. III Yogyakarta: Graha Guru, 2010), h. 32-33

${ }^{10}$ Usman. Menjadi Guru Profesional, (Cet. ke-15. Bandung, PT. Remaja Rosdakarya. 2003), h. 15
} 


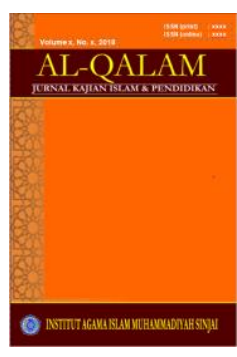

AL-QALAM

Jurnal Kajian Islam \& Pendidikan

Volume 06 No 022014

ISSN (print) : 1858-4152

ISSN (online) : -

Homepage : http://journal.iaimsiniai.ac.id/index.php/al-galam

pendengaran, penglihatan dan hati, semuanya itu akan diminta pertanggungan jawabnya.

Berdasarkan ayat tersebut di atas dapat di simpulkan bahwa kinerja merupakan suatu hasil kerja yang diperoleh seseorang baik secara kuantitatif maupun kualitatif melalui kegiatan - kegiatan atau pengalaman-pengalaman dalam jangka waktu tertentu. Kinerja guru juga merupakan kemampuan yang dihasilkan oleh guru dalam melaksanakan tugas, kewajiban dan tanggung jawabnya yaitu mendidik, mengembangkan ilmu pengetahuan, menjadi orang tua kedua dari anak didik, mencerdaskan dan menciptakan anak didik yang berkualitas.

\section{Upaya Peningkatan Kinerja Guru}

Seiring dengan kemajuan informasi dan teknologi, saat ini terlihat jelas bahwa pihak pengelola pendidikan baik yang berada di tingkat pusat, daerah maupun pada level pelaksana di lapangan sedang terus melaksanakan berbagai upaya peningkatan kinerja guru. Tujuan utama peningkatan kinerja guru adalah untuk mewujudkan niat dan keinginan mencapai prestasi peserta didik yang berkualitas baik dalam rangka merealiasikan visi reformasi pendidikan, yaitu pendidikan harus menghasilkan manusia yang beriman, berakhlak mulia, cerdas serta manusia yang mampu menguasai ilmu pengetahuan dan teknologi ${ }^{11}$. Kegiatan peningkatan kinerja guru dapat dilaksanakan melalui dua pendekatan yaitu kegiatan internal sekolah dan kegiatan eksternal sekolah.

Kompetensi kepribadian merupakan kemampuan yang terdiri dari beberapa sub kompetensi personal yang mencerminkan kepribadian yang mantap, stabil, dewasa, arif, dan berwibawa, menjadi teladan bagi peserta didik, dan berakhlak mulia. Kompetensi pedagogik meliputi pemahaman terhadap peserta didik, perancanaan dan pelaksanaan pembelajaran, evaluasi hasil belajar, dan pengembangan peserta didik untuk mengaktualisasikan berbagai potensi yang di milikinya. Kompetensi professional merupakan penguasaan materi pembelajaran secara luas dan mendalam, yang mencakup penguasaan materi kurikulum mata pelajaran di sekolah dan substansi keilmuan yang menaungi materinya, serta penguasaan terhadap struktur dan metodologi keilmuannya. Kompetensi sosial merupakan kemampuan guru untuk berkomunikasi dan bergaul secara efektif dengan peserta didik, sesama pendidik, tenaga kependidikan, orang tua/wali peserta didik, dan masyarakat.

${ }^{11}$ E. Mulyasa. Kurikulum Berbasis Kompetensi, Cet. II, PT. Remaja Rosdakarya, Bandung: 2003), h. 60 


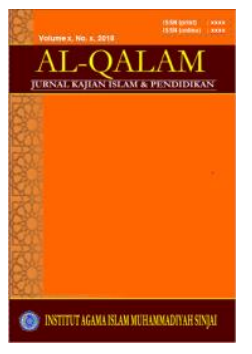

\section{AL-QALAM}

Jurnal Kajian Islam \& Pendidikan

Volume 06 No 022014

ISSN (print) : 1858-4152

ISSN (online) : -

Homepage : http://journal.iaimsiniai.ac.id/index.php/al-qalam

Sertifikasi profesi guru adalah proses untuk memberikan sertifikat kepada guru yang memenuhi standar kualifikasi dan standar kompetensi. Sertifikasi guru bertujuan untuk:

1. Menentukan kelayakan guru dalam melaksanakan tugas sebagai agen pembelajaran dan mewujudkan tujuan pendidikan nasional

2. Meningkatkan proses dan mutu hasil-hasil pendidikan, dan

3. Meningkatkan profesionalisme guru ${ }^{12}$.

\section{Faktor - Faktor yang Mempengaruhi Kinerja}

Kinerja seseorang dipengaruhi oleh kondisi fisiknya. Seseorang yang memiliki kondisi yang baik memiliki daya tahan tubuh yang tinggi yang pada gilirannya tercermin pada kegairahan bekerja dengan tingkat produktivitas yang tinggi, dan begitu juga sebaliknya. Di samping itu kinerja individu berhubungan juga dengan kemampuan yang harus dimiliki oleh individu agar ia berperan dalam organisasi.

Menurut Anwar Prabu Mangkunegara faktor yang mempengaruhi kinerja guru adalah faktor kemampuan (ability) dan faktor motivasi (motivision).

a. Faktor kemampuan

Secara psikologi, kemampuan guru terdiri dari kemampuan potensi (IQ) dan keampuan reality (knowledge + skill). Artinya seorang guru yang memiliki latar belakang pendidikan yang tinggi dan sesuai dengan bidangnya serta terampil dalam mengerjakan pekerjaan sehari-hari, maka ia akan lebih mudah mencapai kinerja yang diharapkan.

Oleh karena itu, pegawai perlu ditetapkan pada pekerjaan yang sesuai dengan keahliannya. Dengan penempatan guru yang sesuai dengan bidangnya akan dapat membantu dalam efetivitas suatu pembelajaran.

b. Faktor motivasi

Motivasi terbentuk dari sikap seorang guru dalam menghadapi situsi kerja. Motivasi merupakan kondisi yang menggerakkan seseorang yang terarah untuk mencapai tujuan pendidikan.

Selanjutnya MeClelland mengemukakan 6 krakteristik dari guru yang memiliki motif berprestasi tinggi Yaitu:

1. Memiliki tanggung jawab pribadi tinggi

2. Berani mengambil resiko

3. Memiliki tujuan yang realistis

${ }^{12}$ Kunandar, Guru Profesional, (Cet. I, Jakarta, PT. Raja Grafindo Persada. 2007), h. 78 


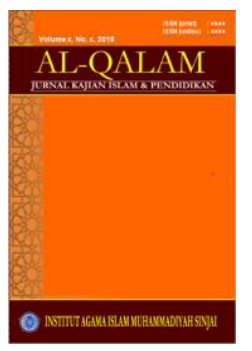

\section{AL-QALAM}

Jurnal Kajian Islam \& Pendidikan

Volume 06 No 022014

ISSN (print) : 1858-4152

ISSN (online) : -

Homepage : http://journal.iaimsiniai.ac.id/index.php/al-qalam

4. Memanfaatkan rencana kerja yang menyeluruh dan berjuang untuk merealisasi tujuannya.

5. Meanfaatkan umpan balik yang kongkret dalam seluruh kegiatan kerja yang dilakukannya.

6. Mencari kesempatan untuk merealisasikan rencana yang telah diprogramkan ${ }^{13}$.

Membicarakan kinerja mengajar guru, tidak dapat dipisahkan faktor-faktor pendukung dan pemecah masalah yang menyebabkan terhambatnya pembelajaran secara baik dan benar dalam rangka pencapaian tujuan yang di harapkan guru dalam mengajar.

Al-Quran memberikan penekanan utama terhadap pekerjaan dan menerangkan dengan jelas bahwa manusia diciptakan di bumi untuk bekerja keras untuk mencari penghidupan masing-masing. Firman Allah Swt, Q.S. AlJum`ah:10 :

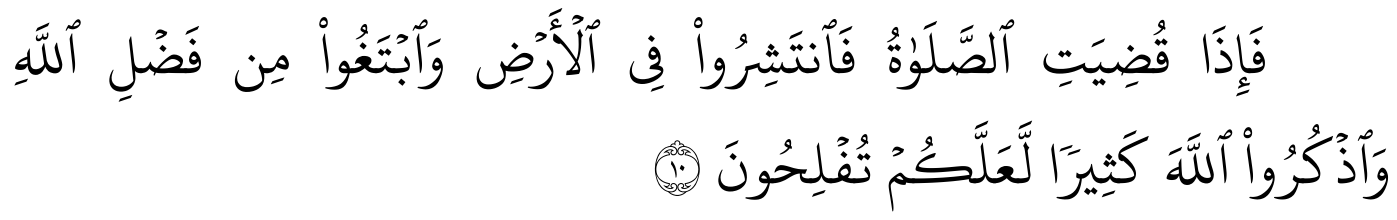

Terjemahan ; Apabila telah ditunaikan shalat, Maka bertebaranlah kamu di muka bumi; dan carilah karunia Allah dan ingatlah Allah banyak-banyak supaya kamu beruntung.

Berdasarkan ayat di atas kita dapat melihat adanya motivasi yang tersirat, yaitu berupa keinginan yang memenuhi kebutuhan dengan cara mencari karunia Allah SWT. Mencari karunia Allah tidaklah dengan berdiam diri, tetapi dengan berusaha dan bekerja untuk memenuhi kebutuhan hidup kita, sehingga terjadi keseimbangan dalam hidup kita untuk kehidupan di dunia dan akhirat.

Dengan demikian Guru sebagai pendidik memiliki tugas dan tanggung jawab yang berat. Guru harus menyadari bahwa ia harus mengerjakan tugasnya tersebut dengan sungguh-sungguh, bertanggung jawab, ikhlas dan tidak asalasalan, sehingga siswa dapat dengan mudah menerima apa saja yang disampaikan oleh gurunya. Jika ini tercapainya maka guru akan memiliki tingkat kinerja yang tinggi.

${ }^{13}$ Anwar Prabu Mangkunegara. Manajemen Sumber Daya Manusia Perusahaan, (Bandung: PT. Remaja Rosdakarya. 2004), h. 67 


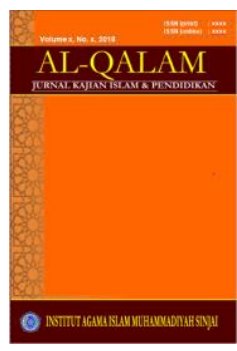

AL-QALAM

Jurnal Kajian Islam \& Pendidikan

Volume 06 No 022014

ISSN (print) : 1858-4152

ISSN (online) : -

Homepage : http://journal.iaimsiniai.ac.id/index.php/al-qalam

Adapun faktor yang mendukung kinerja guru dapat digolongkan ke dalam dua macam yaitu:

a. Faktor dari dalam sendiri (intern)

Di antara faktor dari dalam diri sendiri (intern) adalah

1) Kecerdasan

Kecerdasan memegang peranan penting dalam keberhasilan pelaksanaan tugas-tugas. Semakin rumit dan makmur tugas-tugas yang diemban makin tinggi kecerdasan yang diperlukan. Seseorang yang cerdas jika di berikan tugas yang sederhana dan monoton mungkin akan terasa jenuh dan akan berakibat pada penurunan kinerjanya

2) Keterampilan dan kecakapan

Keterampilan dan kecakapan orang berbeda-beda. Hal ini dikarenakan adanya perbedaan dari berbagai pengalaman dan latihan.

3) Bakat

Penyesuaian antara bakat dan pilihan pekerjaan dapat menjadikan seseorang bekarja dengan pilihan dan keahliannya.

4) Kemampuan dan minat

Syarat untuk mendapatkan ketenangan kerja bagi seseorang adalah tugas dan jabatan yang sesuai dengan kemampuannya. Kemampuan yang disertai dengan minat yang tinggi dapat menunjang pekerjaan yang telah ditekuni

5) Motif

Motif yang dimiliki dapat mendorong meningkatkannya kerja seseorang

6) Kesehatan

Kesehatan dapat membantu proses bekerja seseorang sampai selesai. Jika kesehatan terganggu maka pekerjaan terganggu pula.

7) Kepribadian

Seseorang yang mempunyai kepribadian kuat dan integral tinggi kemungkinan tidak akan banyak mengalami kesulitan dan menyesuaikan diri dengan lingkungan kerja dan interaksi dengan rekan kerja ang akan meningkatkan kerjanya.

8) Cita-cita dan tujuan dalam bekerja

Jika pekerjaan yang diemban seseorang sesuai dengan cita-cita maka tujuan yang hendak di capai dapat terlaksanakan karena ia bekerja secara sungguh-sungguh, rajin, dan bekerja dengan sepenuh hati.

b. Faktor dari luar diri sendiri (ekstern)

Yang termasuk faktor dari luar diri sendiri (ekstern) diantaranya:

1) Lingkungan keluarga 


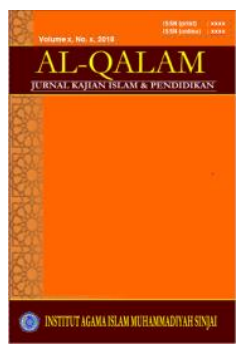

\section{AL-QALAM}

Jurnal Kajian Islam \& Pendidikan

Volume 06 No 022014

ISSN (print) : 1858-4152

ISSN (online) : -

Homepage : http://journal.iaimsiniai.ac.id/index.php/al-qalam

Keadaan lingkungan keluarga dapat mempengaruhi kinerja seseorang. Ketegangan dalam kehidupan keluarga dapat menurunkan gairah kerja.

2) Lingkungan kerja

Situasi kerja yang menyenangkan dapat mendorong seseorang bekerja secara optimal. Tidak jarang kekecewaan dan kegagalan dialami seseorang di tempat ia bekerja. Lingkungan kerja yang dimaksud di sini adalah situasi kerja, rasa aman, gaji yang memadai, kesempatan untuk mengembangan karir, dan rekan kerja yang kologial.

3) Komunikasi dengan kepala sekolah

Komunikasi yang baik di sekolah adalah komunikasi yang efektif. Tidak adanya komunikasi yang efektif dapat mengakibatkan timbulnya salah pengertian

4) Sarana dan prasarana

Adanya sarana dan prasarana yang memadai membantu guru dalam meningkatkan kinerjanya terutama kinerja dalam proses mengajar mengajar ${ }^{14}$.

5) Kegiatan guru di kelas

Peningkatan dan perbaikan pendidikan harus di lakukan secara bertahap. Dinamika guru dalam pengembangan program pembelajaran tidak akan bermakna bagi perbaikan proses dan hasil belajar siswa, jika manajemen sekolahnya tidak memberi peluang tumbuh dan berkembangnya kreatifitas guru. Demikian juga penambahan sumber belajar berupa perpustakaan dan laboratorium tidak akan bermakna jika manajemen sekolahnya tidak memberikan perhatian serius dalam mengoptimalkan pemanfaatan sumber belajar tersebut dalam proses belajar mengajar. Menurut Dede Rosyada dalam bukunya Paradigma Pendidikan Demokratis bahwa kegiatan guru di dalam kelas meliputi:

a) Guru harus menyusun perencanaan pembelajaran yang bijak

b) Guru harus mampu berkomunikasi secara efektif dengan siswasiswanya

c) Guru harus mengembangkan strategi pembelajaran yang membelajarkan

d) Guru harus menguasai kelas

e) Guru harus melakukan evaluasi secara benar ${ }^{15}$.

${ }^{14}$ Kartono Kartini, Menyiapkan dan memadukan Karir, (Jakarta: CV Rajawali. 1985), h. 22

${ }^{15}$ Dede Rosyada., Paradigma Pendidikan Demokratis: Sebuah Model Pelibatan Masyarakat dalam Penyelenggaraan Pendidikan, (Jakarta:PT Kencana. 2004), h. 122 


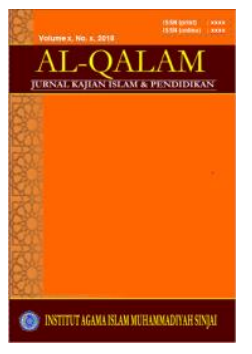

\section{AL-QALAM}

Jurnal Kajian Islam \& Pendidikan

Volume 06 No 022014

ISSN (print) : 1858-4152

ISSN (online) : -

Homepage : http://journal.iaimsiniai.ac.id/index.php/al-qalam

6) Kegiatan guru di sekolah antara lain yaitu:

Berpartisipasi dalam bidang administrasi, di mana dalam bidang administrasi ini para guru memiliki kesempatan yang banyak untuk ikut serta dalam kegiatan-kegiatan sekolah antara lain:

a) Mengembangkan filsafat pendidikan

b) Memperbaiki dan menyesuaikan kurikulum

c) Merencanakan program supervisi

d) Merencanakan kebijakan-kebijakan kepegawaian ${ }^{16}$.

Semua pekerjaan itu harus di kerjakan bersama-sama antara guru yang satu dengan yang lainnya yaitu dengan cara bermusyawarah. Untuk meningkatkan kinerja, para guru harus melihat pada keadaan pemimpinnya (kepala sekolah). Jadi, dapat disimpulkan bahwa baik dan buruknya guru dalam proses belajar mengajar dipengaruhi oleh beberapa faktor salah satunya adalah supervisor dalam melaksanakan pengawasan atau supervisi terhadap kemampuan (kinerja guru).

Kinerja tidak dapat timbul dengan sendirinya, di samping adanya usaha dan kemampuan, kinerja juga dipengaruhi oleh faktor lain. Dilihat dari sudut motivasi, khususnya peganjaran yang akan diperoleh sehubungan dengan adanya kinerja di mana seorang akan melihat bahwa kinerja merupakan jalan yang memuaskan kebutuhan.

\section{Profesionalisme Guru}

Peningkatan kualitas sumber daya manusia merupakan kebutuhan yang sangat mendesak dan perlu mendapat prioritas dari pemerintah pusat dan daerah dalam memasuki era global dan informasi di berbagai bidang. Salah satu strategi dan metode peningkatan kualitas sumber daya manusia yang dikembangkan adalah reformasi dalam bidang pendidikan.

Reformasi dalam bidang pendidikan akan terus di gulirkan melalui berbagai inovasi untuk menyonsong era baru dari paradigma baru dalam bidang pendidikan, yang intinya revitalisasi sistem pembelajaran. Esensi dan rivitalisasi system pembelajaran di antaranya adalah pembelajaran guru dan peningkatan profesionalisme.

Upaya peningkatan kinerja, sangat di tentukan oleh kualitas profesional guru. Hal ini terkait dengan tingkat kompetensi guru, wujud kompetensi guru

16 M. Ngalim Purwanto., Administrasi dan Supervisi Pendidikan, (Jakarta: Remaja Rosdakarya 2003), h. 144-150 


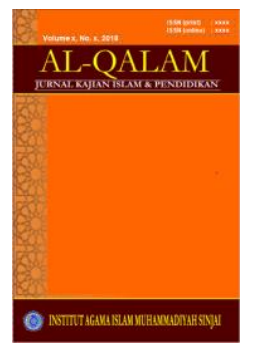

AL-QALAM

Jurnal Kajian Islam \& Pendidikan

Volume 06 No 022014

ISSN (print) : 1858-4152

ISSN (online) : -

Homepage : http://journal.iaimsiniai.ac.id/index.php/al-qalam

tampak pada sejauh mana kemampuan guru untuk memberdayakan potensi peserta didik agar dapat berkembang secara utuh dan optimal diperlukan profesionalisme guru sebagai manajer pendidikan. Kompetensi guru merupakan kemampuan seorang guru dalam melaksanakan kewajiban-kewajiban secara bertanggung jawab dan layak. Berdasarkan pengertian di atas, maka dapat di simpulkan bahwa kompetensi merupakan kemampuan guru dalam melaksanakan tugas profesinya.

Sedangkan profesional adalah orang yang mempunyai keahlian seperti dokter, guru, hakim, dll. Dengan kata lain, bahwa pekerjaan yang bersifat personal adalah pekerjaan yang hanya di lakukan oleh mereka yang khusus di bidangnya. Guru profesional adalah orang yang mempunyai kemampuan dan keahlian khusus dalam bidang keguruan sehingga ia mampu melaksanakan tugas dan fungsinya, kemampuan profesi yang dimiliki oleh seorang guru mencakup, penguasaan kurikulum, materi pelajaran yang diajarkan, keterampilan menggunakan metode yang bervariasi, penggunaan media, keterampilan melaksanakan evaluasi pengajaran, mempunyai tanggung jawab yang tinggi serta memiliki kedisiplinan terhadap tugasnya.

Karena itu keberhasilan pembelajaran sangat di tentukan oleh kemampuan guru dalam mengelola proses belajar mengajar. Karena itu, dalam usaha pengembangan kemampuan profesionalnya guru dituntut untuk terus belajar. Kompetensi daiartikan sebagai kewenangan atau kekuasaan untuk menentukan atau memutuskan suatu hal. Pengertian dasar kompetensi (competency) adalah kemampuan atau kecakapan yang dimiliki oleh seseorang dalam menjalankan tugasnya.

\section{a). Profesi Guru sebagai Pendidik}

Guru sebagai pendidik pada hakekatnya harus berupaya mencapai tujuan institusional pendidik yang utama dan berlaku untuk semua jenjang pendidik yaitu agar lulusan menjadi warga negara yang baik. Sehubungan dengan hal tersebut guru dituntut untuk menanamkan sikap dan dinilai melalui kegiatan belajarmengajar untuk setiap mata pelajaran. Oleh karena itu, guru sebagai pendidik hendaknya: (1) merupakan pelopor pembaharuan, (2) berperan sebagai pimpinan dan pendukung nilai-nilai masyarakat, (3) sebagai fasilitator memungkinkan tercapainya kondisi yang baik bagi para peserta didik, (4) bertanggung jawab atas tercapainya hasil belajar peserta didik, (5) bertanggung jawab sebagai profesional 


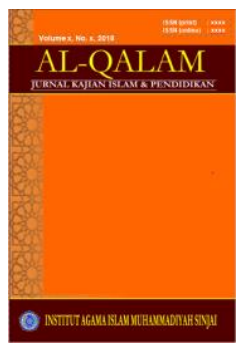

\section{AL-QALAM}

Jurnal Kajian Islam \& Pendidikan

Volume 06 No 022014

ISSN (print) : 1858-4152

ISSN (online) : -

Homepage : http://journal.iaimsiniai.ac.id/index.php/al-qalam

untuk secara terus-menerus meningkatkan kemampuannya, (6) menunjang tinggi kode etika guru ${ }^{17}$.

Tenaga kependidikan merupakan suatu komponen yang penting dalam penyelenggaraan pendidikan, yang bertugas menyelenggarakan kegiatan belajar mengajar, melatih, meneliti, mengembangkan, mengelola dan/ atau memberikan pelayanan teknis dalam bidang pendidikan. Salah satu unsur tenaga kependidikan adalah guru. Karena tugas utama guru adalah mengajar, maka ia harus mempunyai kompetensi atau wewenang mengajar berdasarkan kualifikasi sebagai tenaga pengajar. Sebagai tenaga pengajar, setiap guru harus memiliki kemampuan profesional dalam bidang belajar mengajar atau pembelajaran

\section{b). Profesi Guru sebagai Pengajar}

Salah satu tugas guru adalah menyampaikan ilmu kepada peserta didik. Penyampaian ilmu ini dilakukan dalam proses belajar-mengajar. Hasil belajar peserta didik sebagian besar ditentukan oleh peran guru. Peran guru dalam beberapa hal sangat menentukan sebagaimana yang dikemukakan oleh Moh Uzer Usman sebagai berikut:

a. Guru sebagai Demonstrator.

1) Mengawasi bahan pelajaran.

2) Meningkatkan ilmu pengetahuan dan wawasan keilmuan

3) Memahami kurikulum

4) Mampu merumuskan tujuan pembelajaran khusus

5) Terampil mengelola pembelajaran dengan metode yang sesuai

b. Guru sebagai pengelola kelas.

Sebagai pengelolah kelas. Guru harus menciptakan suasana yang aman dan nyaman. Selain itu guru harus mampu menyediakan sarana kegiatan belajar mengajar yang dapat mendorong semangat peserta didik untuk giat belajar, agar memperoleh hasil yang lebih baik.

c. Guru sebagai mediator

Sebagai mediator guru harus memiliki wawasan pengetahuan yang luas didalam penyediaan media pendidikan dan terampil dalam menggunakan media tersebut.

d. Guru sebagai fasilitator.

${ }^{17}$ Abuddin Nata. Manajemen Pendidikan, Mengatasi Kelemahan Pendidikan Islam di Indonesia (Cet. I; Jakarta : PT. Prenada Media, 2001), h. 139-140 


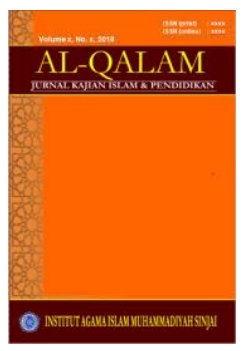

AL-QALAM

Jurnal Kajian Islam \& Pendidikan

Volume 06 No 022014

ISSN (print) : 1858-4152

ISSN (online) : -

Homepage : http://journal.iaimsiniai.ac.id/index.php/al-qalam

Guru sebagai fasilitator, guru hendaknya mampu mengusahakan sumber belajar yang bermanfaat dan dapat menunjang pencapaian tujuan dan kegiatan belajar mengajar.

e. Guru sebagai evaluator

Untuk mengetahui hasil belajar, diperlukan adanya penilaian. Melalui penilaian akan diketahui penguasaan bahan, daya serap materi oleh peserta didik dan sekaligus menjadi ukuran keberhasilan guru dalam mentransfer materi kepada peserta didik.

f. Guru sebagai komunikator

Guru juga bertugas sebagai penghubung antara sekolah dan masyarakat. Guru mempersiapkan rencana awal pembelajaran, kemudian menyusun rencana secara lengkap bersama para peserta didik sebagai persiapan di lapangan. Guru harus mengenal dengan baik keadaan masyarakat sekitarnya, agar dapat menyusun tugas-tugas bagi para peserta didik. Guru harus selalu melakukan inventarisasi masalah-masalah yang muncul dalam masyarakat, kemudian mengupayakan pemecahannya dalam mengadakan diskusi kelas. Peran guru sebagai komunikator bukan saja memerlukan pengetahuan dalam bidang pendidikan dan apresiasi, namun diperlukan pula keterampilan berintegrasi dan bekerja sama dengan masyarakat ${ }^{18}$.

\section{c). Profesi Guru sebagai Pelatih dan Pembimbing}

Profesi guru sebagai pelatih dituntut agar mampu memberikan keterampilan kepada peserta didik dalam memanfaatkan pengetahuan yang dimilikinya (implicated). Dengan program latihan yang berkesinambungan, diharapkan peserta didik tanggap terhadap perkembangan ilmu pengetahuan dan teknologi dan serta memiliki kecintaan dan menghargai setiap keterampilan. Hasil yang diinginkan adalah keluaran (out put) yang terampil dan dapat dipergunakan dalam dunia nyata di masyarakat.

Perkembangan ilmu pengetahuan dan teknologi telah meningkatkan fungsi guru dari sekedar mengajar menjadi seorang pelatih dan pembimbing yang mencakup fungsi guru sebagai perencana pengajar (designer of instruction), pengelolah pengajar (manager of instruction), penilaian hasil belajar ( evaluator of student learning), motivator belajar peserta didik dan pembimbing.

Guru sebagai pembimbing dituntut untuk mengadakan pendekatan bukan saja melalui pendekatan pengajaran, akan tetapi diiringi dengan pendekatan yang

\footnotetext{
${ }^{18}$ Moh. Uzer Usman. Menjadi Guru Profesional. (Cet. VIII; Bandung: Remaja Rosdakarya,1997), h. 19
} 


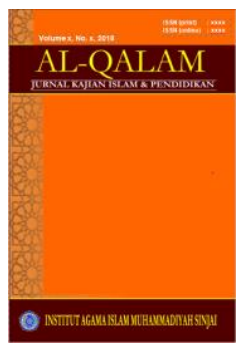

AL-QALAM

Jurnal Kajian Islam \& Pendidikan

Volume 06 No 022014

ISSN (print) : 1858-4152

ISSN (online) : -

Homepage : http://journal.iaimsiniai.ac.id/index.php/al-galam

bersifat pribadi (personal approach) dalam setiap proses belajar mengajar yang berlangsung dengan pendekatan para peserta didiknya secara lebih mendalam sehingga dapat membantu keseluruhan proses belajarnya dan diperoleh hasil belajar yang optimal dengan demikian, guru sebagai pembimbing diharapkan mampu untuk; (1) memberikan berbagai informasi yang diperlukan dalam proses relajar, (2) membantu setiap peserta didik dalam mengatasi masalah pribadi yang dihadapi oleh para peserta didik, (3) mengevaluasi hasil setiap langkah kegiatan yang telah dilakukannya, (4) memberikan kesempatan yang luas agar setiap peserta didik dapat belajar sesuai dengan karakteristik pribadinya, (5) mengenal dan memahami setiap peserta didik baik secara perorangan maupun secara kelompok.

\section{B. Tinjauan Tentang Tingkat Kecerdasan (IQ)}

Kecerdasan adalah kapasitas seseorang untuk memperoleh pengetahuan (belajar dan memahami), mengaplikasikan pengetahuan (memecahkan masalah), dan melakukan penalaran abstrak. ${ }^{19}$ Sedangkan intelegensi adalah kemampuan menghadapi dan menyesuaikan diri terhadap situasi baru secara tepat dan efektif, kemampuan menggunakan konsep abstrak secara efektif, dan kemampuan memahami pertalian-pertalian dan belajar secara cepat. ${ }^{20}$

Berdasarkan pengertian tradisional, kecerdasan meliputi kemampuan membaca, menulis, berhitung, sebagai jalur sempit keterampilan kata dan angka yang menjadi fokus di pendidikan formal (sekolah), dan sesungguhnya mengarahkan seseorang untuk mencapai sukses dibidang akademis. Anak cerdas tentu dambaan setiap orang tua, sebab kecerdasan merupakan modal tak ternilai bagi si anak untuk mengarungi kehidupan dihadapannya. ${ }^{21}$

\section{Tingkatan Kecerdasan (IQ)}

Tingkat kecerdasan peserta didik, mempunyai korelasi yang signifikan terhadap kemampuan belajarnya. Dalam situasi yang sama peserta didik yang mempunyai tingkat kecerdasan tinggi akan lebih sukses dari pada mereka yang

${ }^{19}$ C. George Boeree, Metode Pembelajaran dan Pengajaran, terj. Abdul Qodir Shaleh, (Jogjakarta: Ar-Ruzz Media, 2010), h. 125.

${ }^{20}$ J. P. Chaplin, Kamus lengkap psikologi, terj. Kartini Katono, (Jakarta: Rajawali Pers, 2010), h. 253.

${ }^{21}$ Setiono Mangoenprasodjo dan Sri Nur Hidayati, op. cit, h. 2. 


\section{Volume 06 No 022014}

ISSN (print) : 1858-4152

ISSN (online) : -

memiliki tingkat kecerdasan lebih rendah. Namun demikian tidak selamanya yang mempunyai tingkat kecerdasan tinggi akan berhasil dalam pembelajaran.

Kecerdasan intelegensi (Intelligence Quotient) adalah satu indeks tingkat relative kecermelangan anak, setelah ia dibandingkan dengan anak-anak lain yang seusia. Pengukuran intelegensi yang pertama dilakukan oleh Alfred Binet, pengukuran yang digunakan oleh binet mengambil perbedaan antara usia mental (MA) dan usia kronologis (CA). ${ }^{22}$ Menurut binet intelegensi anak akan terus bertambah sampai umur 15, di atas umur 15 yang bertambah hanyalah pengetahuannya saja. ${ }^{23}$

Berikut adalah Interpretasi atau penafsiran dari IQ :

Tabel 2.1

Interpretasi IQ ${ }^{24}$ :

\begin{tabular}{|c|c|}
\hline TINGKAT KECERDASAN & IQ \\
\hline Genius & Di atas 140 \\
\hline Sangat Super & $120-140$ \\
\hline Super & $110-120$ \\
\hline Normal & $90-110$ \\
\hline Bodoh & $80-90$ \\
\hline Perbatasan & $70-80$ \\
\hline Moron/Dungu & $50-70$ \\
\hline Imbecile & $25-50$ \\
\hline Idiot & $0-25$ \\
\hline
\end{tabular}

William Stern menyempurnakan tes intelegensi Binet, Stern mengembangkannya dengan istilah IQ (Intelligence Quotient) yang menggambarkan inteligensi sebagai rasio antara usia mental (MA) dengan usia kronologis (CA) dengan rumus: $\mathrm{IQ}=. \frac{M A}{C A} \times 100 .^{25}$

22 Desmita, Psikologi Perkembangan, (Bandung: PT Remaja Rosdakarya, 2007).h. 164.

${ }^{23}$ Baharuddin, Psikologi Pendidikan: Refleksi Teoritis Terhadap Fenomena, (Jogjakarta: Ar-Ruzz Media Group, 2010).h. 128.

${ }^{24}$ Setiono Mangoenprasodjo dan Sri Nur Hidayati, op. cit, h. 145

${ }^{25}$ Desmita, Op.Cit, h. 165. 


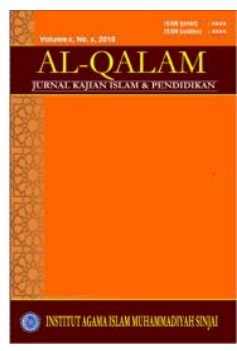

AL-QALAM

Jurnal Kajian Islam \& Pendidikan

Volume 06 No 022014

ISSN (print) : 1858-4152

ISSN (online) : -

Homepage : http://journal.iaimsiniai.ac.id/index.php/al-qalam

Sedangkan Till mengklasifikasi tingkat kecerdasan peserta didik menjadi beberapa tingkatan, yang kemudian banyak dijadikan pedoman dalam melaksanakan bimbingan kepada peserta didik, tingkatan tersebut sebagai berikut:

a. Golongan yang terendah adalah mereka yang memiliki IQ antara 0-50.

Tingkat kecerdasan peserta didik (0-25) tergolong tidak dapat didik atau dilatih. Mereka hanya mampu belajar tidak lebih dari dua tahun. Sedangkan mereka yang tergolong dalam IQ antara 25-50 bisa dididik untuk mengurus kegiatan rutin yang sederhana atau untuk mengurus kebutuhan jasmaninya. Dua golongan ini dinyatakan sebagai keterbatasan mental, lemah pikiran atau cacat mental, ada pula yang menyebutnya dengan idiot dan imbicili.

b. Tingkat kecerdasan peserta didik dengan IQ 50-70.

Dikenal dengan golongan moron, memiliki keterbatasan atau kelambatan mental. Mereka dapat dididik, dapat belajar membaca, menulis, berhitung sederhana, dan dapat mengembangkan kecakapan bekerja secara terbatas.

c. Tingkat kecerdasan peserta didik dengan IQ antara 70-90.

Disebut sebagai anak lambat, kelompok anak ini dapat dibantu dengan pemanfaatan metode, bahan dan alat yang tepat, di samping kesabaran guru.

d. Tingkat kecerdasan peserta didik dengan IQ 90-110,

Disebut juga dengan golongan menengah, yang merupakan bagian yang paling besar jumlahnya. Mereka bisa belajar normal.

e. Tingkat kecerdasan peserta didik dengan IQ 110-130.

Golongan ini ada yang menyebutnya dengan nama peserta didik yang cepat mengerti ada juga dengan nama superior.

f. Tingkat kecerdasan peserta didik dengan IQ 140 ke atas.

Disebut jenius, mereka mampu belajar jauh lebih cepat dari golongan lainnya. Craig dkk menyebutkan ciri-ciri anak jenius sebagai berikut:

1. Belajar dengan cepat dan mudah;

2. Mempertahankan (menyimpan) apa yang dipelajari;

3. Menunjukkan rasa ingin tahu;

4. Memiliki perbendaharaan kata yang baik, mampu membaca dengan baik, dan menyenangi kegiatan tersebut;

5. Memiliki kemampuan berfikir logis, membuat generalisasi, dan melihat hubungan-hubungan;

6. Lebih sehat dan lebih mampu menyesuaikan diri dari pada anak-anak kelompok normal;

7. Dan mencari teman yang lebih tua. 


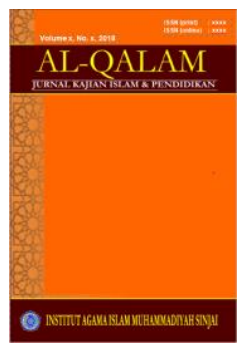

AL-QALAM

Jurnal Kajian Islam \& Pendidikan

Volume 06 No 022014

ISSN (print) : 1858-4152

ISSN (online) : -

Homepage : http://journal.iaimsiniai.ac.id/index.php/al-qalam

Pengelompokan IQ tersebut sangat penting untuk dipahami guru sebagai dasar untuk mengetahui tingkat kecerdasan peserta didik, dalam rangka menentukan strategi pembelajaran yang efektif dan efesien bagi peserta didik, di samping itu guru harus mempunyai patokan secara sistimatis dan menyeluruh dalam melayani peserta didik agar hasil belajarnya tidak semata-mata ditentukan oleh tingkat kemampuan intelektualitasnya, namun banyak faktor lain yang dapat mempengaruhinya seperti motivasi, sikap, dan kesehatan. ${ }^{26}$

\section{Faktor-faktor yang mempengaruhi perkembangan IQ}

IQ cukup memegang peranan penting untuk suksesnya seorang anak dalam belajar banyak hal. Menurut penelitian, IQ atau daya tangkap seseorang, mulai dapat ditentukan sekitar usia 3 tahun, yaitu saat ia mulai banyak mengucapkan kata-kata. Karena, ada hubungan langsung antara kemampuan berbahasa si anak dengan IQ-nya. Seorang anak yang meiliki IQ tinggi, penguasaan bahasanya akan cepat dan banyak. Tinggi rendahnya IQ seorang anak, dapat dipengaruhi oleh banyak fakor. Secara garis besar, faktor-faktor tersebut dapat digolongkan menjadi 3, yaitu :

1. Faktor Genetik

Menurut hasil penelitian, kecerdasan dapat diturunkan melalui gen-gen dalam kromosom. Untuk itu, tidak heran jika ayah-ibu yang cerdas, akan melahirkan anak yang cerdas pula. Bahkan kini di luar negeri, terdapat bank sperma dari para donor pria-pria jenius.

2. Faktor Gizi

Gizi yang baik sangat penting untuk pertumbuhan sel-sel otak, terutama pada saat ibu hamil dan juga pada waktu bayi, yaitu pada saat sel-sel otak sedang tumbuh dengan pesatnya. Kekurangan gizi pada saat pertumbuhan, bisa berakibat berkurangnya jumlah sel-sel otak dari jumlah yang normal. Hal itu tentu saja akan mempengaruhi kerja otak tersebut dikemudian hari.

3. Faktor Lingkungan

Lingkungan yang baik adalah lingkungan yang dapat memberikan kebutuhan mental bagi si anak. Kebutuhan mental meliputi kasih sayang, rasa aman, pengertian, perhatian, penghargaan, serta rangsangan intelektual. Kekurangan rangsangan intelektual pada masa bayi dan balita, dapat

${ }^{26}$ Tohirin, Psikologi Pembelajaran Pendidikan Agama Islam Berbasis Integrasi dan Kompetensi, (Jakarta: Raja Grafindo Persada, 2008), h. 85. 


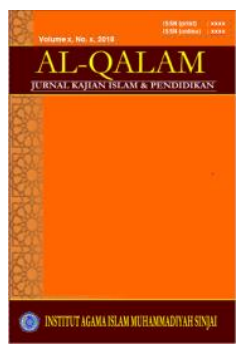

AL-QALAM

Jurnal Kajian Islam \& Pendidikan

Volume 06 No 022014

ISSN (print) : 1858-4152

ISSN (online) : -

Homepage : http://journal.iaimsiniai.ac.id/index.php/al-qalam

menyebabkan hambatan pada perkembangan kecerdasannya. Untuk itu, kewajiban orang tua untuk menciptakan lingkungan keluarga yang kondusif untuk merangsang intelektual si anak dalam mengasah IQ-nya. ${ }^{27}$

IQ atau daya tangkap ini dianggap tidak akan berubah sampai seseorang dewasa. Namun dalam perkembangannya, ditemukan beberapa penyebab yang dapat merubah IQ seseorang, di antaranya :

1. Penyebab organo-biologis.

Yaitu segala kerusakan yang terjadi pada sel-sel otak yang bisa diakibatkan oleh penyakit, tumor otak, kecelakaan, ataupun kurang gizi. Makin berat kerusakan sel-sel otak, makin berat pula gangguannya terhadap fungsi otak.

2. Penyebab psiko sosial

Yaitu hambatan-hambatan yang disebabkan oleh ingkungan, misalnya kekurangan rangsangan mental pada bayi dan anak. Hal ini biasanya disebabkan oleh ketidakmampuan orang tua, juga oleh faktor kemiskinan. Pada golongan sosio-ekonomi yang rendah, segala energi dari orang tua dicurahkan untuk mencukupi kebutuhan sandang dan pangan, sehingga orang tua tidak mempunyai waktu untuk mendidik anak-anak. Kebanyakan anak-anak itu dibiarakan tumbuh sendiri dan meniru apa yang mereka lihat di lingkungannya.

3. Penyebab kelainan kromosom

Terjadinya kelainan kromosom dapat menyebabkan anak-anak menjadi terbelakang mentalnya. Dala dunia kedokteran, anak-anak yang menderita keterbelakangan mental termasuk dalam golongan "mongoloid" karena memiliki penampilan yang sama, seperti bentuk tubuhnya pendek gemuk, jari tangannya pendek, matanya sipit dan ujungnya miring ke atas, hidungnya pesek, mulutnya kecil dengan ujung ke bawah. Anak-anak ini tentunya memiliki IQ rendah. ${ }^{28}$

\section{SIMPULAN}

1. Kompetensi kepribadian merupakan kemampuan yang terdiri dari beberapa sub kompetensi personal yang mencerminkan kepribadian yang mantap, stabil, dewasa, arif, dan berwibawa, menjadi teladan bagi peserta didik, dan berakhlak mulia. Kompetensi pedagogik meliputi pemahaman terhadap peserta didik, perancanaan dan pelaksanaan pembelajaran,

${ }^{27}$ Setiono Mangoenprasodjo dan Sri Nur Hidayati, op. cit, h. 155.

${ }^{28}$ Ibid, h. 156. 


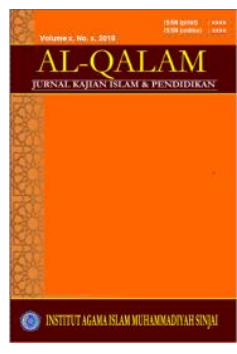

AL-QALAM

Jurnal Kajian Islam \& Pendidikan

Volume 06 No 022014

ISSN (print) : 1858-4152

ISSN (online) : -

Homepage : http://journal.iaimsiniai.ac.id/index.php/al-qalam

evaluasi hasil belajar, dan pengembangan peserta didik untuk mengaktualisasikan berbagai potensi yang di milikinya. Kompetensi professional merupakan penguasaan materi pembelajaran secara luas dan mendalam, yang mencakup penguasaan materi kurikulum mata pelajaran di sekolah dan substansi keilmuan yang menaungi materinya, serta penguasaan terhadap struktur dan metodologi keilmuannya. Kompetensi sosial merupakan kemampuan guru untuk berkomunikasi dan bergaul secara efektif dengan peserta didik, sesama pendidik, tenaga kependidikan, orang tua/wali peserta didik, dan masyarakat.

2. Tingkat kecerdasan peserta didik, mempunyai korelasi yang signifikan terhadap kemampuan belajarnya. Dalam situasi yang sama peserta didik yang mempunyai tingkat kecerdasan tinggi akan lebih sukses dari pada mereka yang memiliki tingkat kecerdasan lebih rendah. Namun tidak selamanya yang mempunyai tingkat kecerdasan tinggi akan berhasil dalam pembelajaran. Dengan demikian seorang guru diharapkan mampu mengarahkan peserta didik dalam mengembangkan kecerdesan intelegensi IQ sehingga peserta didik tidak menemukan kendala dan mampu keluar dalam berbagai macam permasalahan dalam proses pembelajaran yang dihadapi oleh peserta didik.

\section{DAFTAR PUSTAKA}

As'ad, Muhammad.. Psikologi Industri: Seri Sumber Daya Manusia. Yogjakarta : Liberty. 2003

Baharuddin, Psikologi Pendidikan: Refleksi Teoritis Terhadap Fenomena, Jogjakarta: Ar-Ruzz Media Group, 2010

Boeree, C. George, Metode Pembelajaran dan Pengajaran, terj. Abdul Qodir Shaleh, Jogjakarta: Ar-Ruzz Media, 2010

Chaplin, J. P. Kamus lengkap psikologi, terj. Kartini Katono, Jakarta: Rajawali Pers, 2010

Departemen Pendidikan dan Kebudayaan, Kamus Besar Bahasa Indonesia, Edisi Kedua Balai Pustaka. 1991

Desmita, Psikologi Perkembangan, Bandung: PT Remaja Rosdakarya, 2007

Getteng, Rahman Abd., Menuju Guru Profesional dan Ber-Etika, Cet. III Yogyakarta: Graha Guru, 2010

Kartini, Kartono, Menyiapkan dan memadukan Karir, Jakarta: CV Rajawali. 1985

Kunandar, Guru Profesional, Cet. I, Jakarta, PT. Raja Grafindo Persada. 2007 


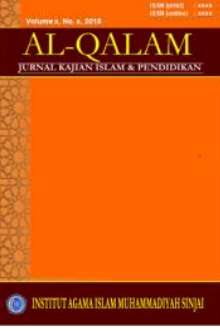

\section{AL-QALAM}

Jurnal Kajian Islam \& Pendidikan

Volume 06 No 022014

ISSN (print) : 1858-4152

ISSN (online) : -

Homepage : http://journal.iaimsiniai.ac.id/index.php/al-qalam

Mangkunegara, Prabu Anwar. Manajemen Sumber Daya Manusia Perusahaan, Bandung: PT. Remaja Rosdakarya. 2004

Mulyasa, E. Kurikulum Berbasis Kompetensi, Cet. II, PT. Remaja Rosdakarya, Bandung: 2003

Nata, Abuddin. Manajemen Pendidikan, Mengatasi Kelemahan Pendidikan Islam di Indonesia Cet. I; Jakarta : PT. Prenada Media, 2001

Purwanto, Ngalim M. Administrasi dan Supervisi Pendidikan, Jakarta: Remaja Rosdakarya 2003

Rosyada, Dede, Paradigma Pendidikan Demokratis: Sebuah Model Pelibatan Masyarakat dalam Penyelenggaraan Pendidikan, Jakarta:PT Kencana. 2004

Saroni, Mohammad, Personal Branding Guru, Cet, I; Jogjakarta: Ar-Ruzz Media, 2010

Slameto, Belajar dan Faktor-faktor yang Mempengaruhinya, Jakarta: Rineka Cipta, 2003

Tohirin, Psikologi Pembelajaran Pendidikan Agama Islam Berbasis Integrasi dan Kompetensi, Jakarta: Raja Grafindo Persada, 2008

Undang-Undang Nomor 14 Tahun 2005. tentang Guru dan Dosen, Jakarta : CV. Tamita Utama

Usman. Menjadi Guru Profesional, Cet. ke-15. Bandung, PT. Remaja Rosdakarya. 2003

Usman, Uzer Moh.. Menjadi Guru Profesional. Cet. VIII; Bandung: Remaja Rosdakarya, 1997

Yaslis, Ilyas, Kinerja, Teori, Penilaian dan Penelitian. Jakarta: Pusat Kajian Ekonomi Kesehatan FKM Universitas Indonesia. 2002 